\title{
Anti-inflammatory Therapy for Coronary Atherosclerotic Heart Disease: Unanswered Questions Behind Existing Successes
}

\author{
Jun $\mathrm{Ma}^{1,2}$ and Xiaoping Chen ${ }^{1 *}$ \\ ${ }^{1}$ Department of Cardiology, West China Hospital, Sichuan University, Chengdu, China, ${ }^{2}$ Department of Cardiology, The \\ General Hospital of Western Theater Command, Chengdu, China
}

OPEN ACCESS

Edited by:

Murali Vijayan

Texas Tech University Health Sciences

Center, United States

Reviewed by:

Somasundaram Raghavan,

University of Tennessee Health

Science Center (UTHSC),

United States

Aristeidis H. Katsanos,

McMaster University, Canada

M. Dennis Leo,

University of Tennessee Health

Science Center (UTHSC),

United States

Qiang Zhao,

Georgia State University, United States

*Correspondence: Xiaoping Chen

xiaopingchen23@163.com

Specialty section:

This article was submitted to Cardiovascular Metabolism,

a section of the journal

Frontiers in Cardiovascular Medicine

Received: 20 November 2020 Accepted: 21 December 2020 Published: 01 February 2021

Citation:

Ma J and Chen X (2021) Anti-inflammatory Therapy for Coronary Atherosclerotic Heart Disease: Unanswered Questions

Behind Existing Successes.

Front. Cardiovasc. Med. 7:631398.

doi: $10.3389 /$ fcvm.2020.631398
Coronary atherosclerotic heart disease is a serious threat to human health. The results of the Canakinumab Anti-Inflammatory Thrombosis Outcome Study published in 2017 put an end to the perennial debate about the anti-inflammatory treatment of coronary atherosclerotic heart disease. In addition to interleukin $1 \beta$ monoclonal antibody, interleukin 6 receptor antagonists and colchicine have also shown exciting results in clinical trials within the last 3 years. However, behind these successes, questions remain that need to be addressed. In this review, we summarize the successes and existing doubts of interleukin $1 \beta$ antibodies, interleukin 6 receptor antagonists, and colchicine in the anti-inflammatory treatment of coronary atherosclerotic heart disease.

\footnotetext{
Keywords: atherosclerotic heart disease, interleukin $1 \beta$ (IL-1 $\beta$ ), interleukin 6 (IL-6), colchicine, anti-inflammatory therapy
}

The occurrence and development of coronary atherosclerotic heart disease are thought to be associated with a variety of risk factors, including hypertension, hyperlipidemia, diabetes mellitus, smoking, etc. $(1,2)$. Prevention and control of coronary heart disease through strict control of risk factors can be significantly effective (3). However, a previous study showed that even in low-risk populations without appealing risk factors, a significant proportion of the population still suffered from coronary atherosclerotic heart disease (4). On the other hand, standard treatment after a percutaneous coronary intervention (PCI) failed to inhibit the progression of non-offending coronary plaque (5). Therefore, the treatment of coronary artery disease still needs further refinement.

Inflammation is an important contributor to the development and progression of atherosclerotic plaque (6-8); diseases characterized by chronic inflammation (for example, rheumatism and gout) are disproportionately burdened by coronary atherosclerotic heart disease (9-12). Analyses of randomized human trials showed that patients with coronary artery disease could further benefit from lowering low-density cholesterol (LDL-C) if they also reduce the risk of inflammation (13-16), and statins were highly effective in patients with elevated high-sensitivity C-reactive protein (hsCRP) and low levels of LDL-C $(17,18)$. As evidence from basic and clinical studies accumulates, many researchers believe that anti-inflammatory therapy could be a new option to break the bottleneck in the treatment of atherosclerotic heart disease. Thus, researchers have conducted a series of clinical trials on inflammation and coronary artery disease. The results showed that anti-inflammatory therapy might become an important tool for optimizing existing coronary drug therapy. However, behind the success, there are still questions. This article summarized the successes and unanswered questions of current anti-inflammatory treatments for coronary atherosclerotic heart disease and provided a discussion. 


\section{PATH TO SUCCESS IN CLINICAL STUDIES}

A series of clinical trials have been conducted in recent years for the anti-inflammatory treatment of coronary atherosclerotic hearts, including but not limited to Anti-inflammatory Therapy with Canakinumab for Atherosclerotic Disease (CANTOS) (19), Low-Dose Methotrexate for the Prevention of Atherosclerotic Events (20), Low-Dose Colchicine for Secondary Prevention of Cardiovascular Disease (LoDoCo) (21), Colchicine in Patients with Chronic Coronary Disease (LoDoCo2) (22), etc. These clinical trials can be divided into two categories (Table 1): therapy with a clear target (most are inflammation-related cytokines), such as CANTOS, and broad-spectrum antiinflammatory approach, such as LoDoCo series trials and LowDose Methotrexate for the Prevention of Atherosclerotic Events. From the results so far, the drugs targeting interleukin (IL)-6 receptor/IL-1 $\beta$ have achieved positive results, whereas the low dose of colchicine is the most promising for the broad-spectrum anti-inflammatory approach.

Historically, the evidence for the involvement of inflammation in the formation of atherosclerosis has been accumulated for more than 30 years $(30,31)$. Although basic research suggests that activation of many inflammatory factors or inflammatory pathways promotes the development of atherosclerotic disease (30), the current clinical findings suggest that the key point of anti-inflammatory treatment of atherosclerotic disease is most likely present in the IL-1 $\beta / \mathrm{IL}-6 / \mathrm{C}$-reactive protein (CRP) pathway. Tracing the footsteps of several successful clinical trials to date, we can divide the history of research development in anti-inflammatory therapy for atherosclerotic heart disease into three stages: from 1990 to 1999, the work done by researchers was mainly observational research trials in which they discovered the important predictive role of CRP in the occurrence of adverse cardiovascular events in patients with coronary heart disease (32-35); then from 2000 to 2009, researchers began to look for further clues linking inflammation to coronary heart disease and tried to find suitable therapeutic targets. They found that CRP is better suited as a biomarker than a therapeutic target, and instead, the key CRP upstream protein, IL-6, is a potential therapeutic target (36-38); over the past decade, researchers have conducted a series of clinical drug trials for the antiinflammatory treatment of coronary atherosclerotic heart disease and have achieved important results. Among them, the drugs with positive results are mainly IL-1 $\beta$ monoclonal antibodies, IL-6 receptor antagonists (IL-6Ra), and the traditional antiinflammatory drug colchicine.

\section{WHAT UNANSWERED QUESTIONS LIE BEHIND THE SUCCESS?}

\section{Interleukin-6 Receptor Antagonist in the Treatment of Coronary Atherosclerotic Heart Disease}

IL-6 is the main upstream protein of CRP (39). Basic studies have shown that IL-6 is associated with plaque initiation and instability (40). CRP or hsCRP is an important marker for predicting the risk of cardiovascular events in coronary atherosclerotic heart disease. Although lowering CRP levels can improve outcomes in patients with coronary heart disease (41), genetic polymorphisms in CRP in the population are not significantly associated with disease risk of ischemic vascular disease (36), and researchers consider CRP itself is unlikely to provide an effective target for intervention (39). For these reasons, researchers moved to IL6; they found that elevated levels of IL-6 are associated with increased risk of future myocardial infarction (MI) in healthy men (42) and treatment with tocilizumab (IL-6Ra) significantly attenuates inflammation and PCI-related troponin $\mathrm{T}$ release in patients with acute non-ST-elevation myocardial infarction (NSTEMI) (23). Mendelian randomization studies demonstrate that polymorphism in the IL-6 signaling pathway at rs2228145 and rs7529229 concordantly associate with both lifetime lower levels of hsCRP and lifetime lower risks of coronary heart disease $(40,43)$. Next, researchers designed a clinical trial to evaluate the effect of tocilizumab on myocardial salvage in patients with acute ST-elevation myocardial infarction (STEMI), and this clinical trial is called the ASSAIL-MI trial. The trial was a multicenter randomized controlled trial that ultimately included 199 subjects, randomly assigned 1:1 to a tocilizumab treatment group and a placebo group; subjects in both groups assess the efficacy of treatment at 3-7 days, 3 months, and 6 months of follow-up, respectively (24). The results published in European Society of Cardiology Congress 2020 showed that treatment of patients after first acute STEMI with tocilizumab significantly improved the myocardial salvage index. In a prespecified subgroup analysis, it was found that patients with ischemic episodes lasting longer than $3 \mathrm{~h}$ before PCI had a more significant effect with tocilizumab. Therefore, IL-6 is an important anti-inflammatory therapeutic target for MI patients.

\section{Efficacy and Safety of Long-Term Use of Interleukin-6 Receptor Antagonists Needs to Be Further Evaluated}

The clinical evidence for IL-6Ra is insufficient compared with IL-1 $\beta$ and colchicine. There are no large randomized controlled studies of IL-6Ra with major cardiovascular events as endpoints. The long-term prognostic effect of IL- 6 antibodies in coronary atherosclerotic disease is unclear. A potential limitation of longterm treatment with direct IL-6 inhibition is that this approach may upregulate apolipoprotein B, leading to an increase in LDL$\mathrm{C}$, and this effect was dose-dependent, potentially unrelated to inflammatory status, and thus a significant limiting factor in the development of IL-6 receptor blockade for atherosclerosis (4446). In fact, the possible actions for IL-6 involved in coronary atherosclerotic heart disease included initiation and progression of atherogenesis (47), the stability of atherosclerotic plaques (48), thrombosis (49), myocardial ischemia/reperfusion injury, ventricular remodeling, and development of heart failure $(50,51)$. Researchers who designed the ASSAIL-MI trial also focused on the effect of tocilizumab in ischemia/reperfusion injury and myocardial remodeling after MI but did not address the atherogenesis and stability of atherosclerosis (24). Thus, it seems 


\begin{tabular}{|c|c|c|c|c|c|c|c|c|}
\hline Trial name & Study design & Study population & $\begin{array}{l}\text { Patient } \\
\text { number }\end{array}$ & $\begin{array}{l}\text { Follow- } \\
\text { up } \\
\text { (years) }\end{array}$ & Intervention & Target & Primary outcomes & Result \\
\hline
\end{tabular}

\section{Therapy with a clear target}

Effect of a single dose of Phase II,

Patients with NSTEM

the interleukin-6 receptor two-center, double-blind,

antagonist tocilizumab on placebo-controlled trial

inflammation and troponin

Trelease in patients with

non-ST-elevation

myocardial infarction (23)

Phase I

randomized,

double blind, placebo-controlled onset of chest pain

tria

MRC-ILA Heart (25)

Phase II, double-blinded,

Patients with NSTE-ACS,

randomized, placebo-controlled presenting $<48 \mathrm{~h}$ from onset of

chest pain

CANTOS (19)

Phase III multicenter, randomized, double-blind, placebo-controlled

LATITUDE-TIMI 60 (26) Phase III multicenter, randomized, double-blind, placebo-controlled

SOLID-TIMI 52 (27)

Phase III multicenter, randomized, double-blind, placebo-controlled

\section{Broad-spectrum anti-inflammatory approach}

CIRT (20)

$$
\begin{aligned}
& \text { Phase III multicenter, } \\
& \text { randomized, double-blind, }
\end{aligned}
$$

placebo- controlled trial

LoDoCo (21)

Prospective, randomized,

observer-blinded
Patients with $\mathrm{Ml}$ and

elevated hsCRP

Patients had been hospitalize with a presumed spontaneous (type 1) MI

Patients within 30 days of hospitalization with an ACS

Patients with previous

myocardial infarction or

multivessel coronary disease

who additionally had either

type 2 diabetes or the

metabolic syndrome

Patients with stable coronary

disease
117

0.5

zumab $280 \mathrm{mg} \quad$ II-6ra prior to coronary

angiography vs.

Placebo

199

0.5

Tocilizumab 20

Placebo

1.0 $100 \mathrm{mg}$ of anakinra $\quad \|-1 \mathrm{ra}$

once daily vs.

Placebo

10,061

2.1 Canakinumab (50, $\quad \|-1 \beta$

150 , or $300 \mathrm{mg}$ )

every 3 months vs.

Placebo

3,503 0.4 Twice-daily Mapk

losmapimod $7.5 \mathrm{mg}$

vs. Placebo

13,026

2.5 Once-daily

darapladib $160 \mathrm{mg}$

vs. Placebo

Lp-pla 2

(n)

target dose of

$15-20 \mathrm{mg}$ weekly)

vs. Placebo

532
3.0 Colchicine
$0.5 \mathrm{mg} /$ day vs.
Placebo

Auc for hscrp during hospitalization $4.2 \mathrm{mg} / \mathrm{L} / \mathrm{h}$ (placebo) vs. 2.0 $\mathrm{mg} / \mathrm{L} / \mathrm{h}$ (tocilizumab): $\mathrm{p}<$ 0.001

Completed, results not published

Auc for c-reactive protein over the first 7 days

IL-1Ra group, $21.98 \mathrm{mg}$ day/L (95\%Cl 16.31-29.64) vs. placebo group, $43.5 \mathrm{mg}$ day/L (31.15-60.75); $p=$ 0.0028

Non-fatal mi, non-fatal stroke and $\quad H R \quad 0.85 ; 95 \% \mathrm{Cl} 0.75-0.98$; cardiovascular death

$p=0.021$ in $150 \mathrm{mg}$ treated group

Composite of cardiovascular death, HR 1.16; $95 \% \mathrm{Cl}$,

$\mathrm{mi}$, or severe recurrent ischemia $\quad 0.91-1.47 ; p=0.24$ requiring urgent coronary revascularization

Composite of coronary heart $\quad H R 1.00 ; 95 \% \mathrm{Cl}$, disease (chd) death, mi, or urgent $\quad 0.91-1.09 ; p=0.93$ coronary revascularization for myocardial ischemia

Non-fatal mi, non-fatal stroke and cardiovascular death

HR 1.01; 95\% Cl 0.82-1.25; $p=0.91$

Composite incidence of acute

HR 0.29; $95 \%$ Cl: 0.15 to coronary syndrome, out-of-hospital $0.56 ; p<0.001$ cardiac arrest, or

non-cardioembolic ischemic stroke 
that from the current clinical studies that anti-IL-6 primarily acts on the myocardium rather than on vascular plaques.

In addition, although no significant adverse effects were observed with IL-6Ra at 6 months (23), the safety of longterm tocilizumab use was not fully assured. The CANTOS clinical trial showed that the incidence of fatal infections and sepsis was significantly higher in the canakinumab (a therapeutic monoclonal antibody targeting IL-1 $\beta$ ) group, and the IL-6 levels in the canakinumab group were significantly lower than baseline (19). Considering the anti-inflammatory effects of IL-6 (52-55), the long-term safety of IL-6Ra still needs to be validated by clinical trials with long-term follow-up.

\section{Therapeutic Monoclonal Antibody Targeting Interleukin-1 $\beta$ in Treatment of Coronary Atherosclerotic Heart Disease}

One of the important upstream pathways of IL- 6 is the IL1 signaling pathway. It has been proved that deficiency in or delivery of an antagonist of the receptor for IL-1 (IL-1R) in mice unequivocally results in reductions in atherosclerosis (56). In clinical trials, although IL-1Ra treatment reduced inflammatory markers in NSTEMI patients at 14 days after NSTEMI, major adverse cardiovascular events at 30 days and 3 months were similar in the IL-1Ra group as in the control group and occurred at a higher rate at 1 year (25). IL-1 $\beta$ is the primary circulating form of IL-1 and then has been much focused; basic studies have shown that IL-1 $\beta$ deficiency decreases the severity of atherosclerosis (57). CANTOS is the first large-scale clinical trial to prove the effectiveness of anti-inflammatory treatment for coronary atherosclerotic heart disease and the inflammation hypothesis of atherosclerotic disease. The trial enrolled 10,061 patients with previous MI and hsCRP level of $2 \mathrm{mg}$ or more per liter and compared three doses of canakinumab $(50,150$, and $300 \mathrm{mg}$, administered subcutaneously every 3 months) with placebo. The results show that canakinumab significantly reduced hsCRP level, as compared with placebo, without reducing the LDL-C level, and the 150-mg dose resulted in a significantly lower incidence of recurrent cardiovascular events than placebo after 2-year follow-up (19). After a median of 3.7 years of follow-up, canakinumab reduced the rates of total serious cardiovascular events, with rates per 100 person-years in the placebo, 50-, 150-, and 300-mg canakinumab groups of 10.4, $8.4,8.3$, and 8.2 , respectively (58). The results suggest that all three doses of canakinumab can work.

\section{Clinical Use of Interleukin-1 $\beta$ Monoclonal Antibody Faces Difficulties}

The IL-1 $\beta$ monoclonal antibody in the treatment of coronary atherosclerotic heart disease is also facing some problems. Despite the positive results with CANTOS, canakinumab was not approved for clinical use in patients so far. This may be due to the high price of canakinumab as well as the risk of serious infection (19). More recently, the CANTOS trial group reported that there remains a substantial residual inflammatory risk related to both IL-18 and IL- 6 after IL-1 $\beta$ inhibition with canakinumab (59). Therapeutic monoclonal antibody targeting IL- $1 \beta$ confirms the 
inflammatory theory of atherosclerotic heart disease but is still far from clinical treatment.

Additionally, researchers who designed CANTOS believe that canakinumab reduces atherothrombosis by acting directly on IL-1 $\beta$ in the circulation (39), but basic research shows that IL-1 $\beta$ promotes multiple beneficial changes in latestage murine atherosclerosis, including promoting outward remodeling and formation and maintenance of a smooth muscle cell/collagen-rich fibrous cap (60). Therefore, the role of IL- $1 \beta$ in atherosclerotic plaques remains to be discussed.

\section{Colchicine in Treatment of Coronary Atherosclerotic Heart Disease}

From the results of current studies, colchicine is the most promising drug for clinical use in the treatment of coronary atherosclerotic heart disease. As a common anti-inflammatory drug $(61,62)$ for the treatment of acute gout and rheumatism, colchicine not only has the advantage of being inexpensive and safe (63-66) but also shows a protective effect against cardiovascular diseases in gout patients. A retrospective study reported in 2012 show that gout patients who took colchicine had a significantly lower prevalence of MI vs. those who did not take colchicine (1.2 compared with $2.6 \%, P=0.03$; $54 \%$ relative risk reduction) (67), and Solomon et al. (68) show that colchicine used in gout patients was associated with a $49 \%$ relative risk reduction in a composite primary outcome of MI, stroke, and transient ischemic attack compared with patients who did not use colchicine, as well as a $73 \%$ relative risk reduction in all-cause mortality. The potential for treating coronary atherosclerotic heart disease demonstrated by colchicine has attracted researchers to design a series of relevant clinical trials. Stefan et al. (21) designed a prospective, randomized, observer-blinded clinical trial and found that the addition of 0.5-mg colchicine daily significantly reduced adverse cardiovascular events in patients with stable coronary artery disease under regular secondary prevention therapies compared with no addition of colchicine (4.5 vs. $16.0 \%$; hazard ratio: 0.29 ; $95 \% \mathrm{CI}: 0.15$ to $0.56 ; p<0.001$ ), and this trial is also called the LoDoCo study. Building upon the positive result, researchers conducted the LoDoCo2 study, a phase 3 multicenter, double-blind, randomized placebo-controlled clinical trial. The LoDoCo2 randomized 5,522 patients with stable atherosclerosis to receive either $0.5 \mathrm{mg} /$ day of colchicine or a matching placebo in addition to proven secondary prevention therapies. After an average follow-up of 28.6 months, the result demonstrates that $0.5 \mathrm{mg}$ of colchicine once daily resulted in a $31 \%$ lower relative risk of the primary endpoint (cardiovascular death, spontaneous MI, ischemic stroke, or ischemia-driven coronary revascularization) than placebo, with a hazard ratio of 0.69 (22). In addition, colchicine also has a protective effect in post-MI patients. The Efficacy and Safety of LowDose Colchicine after Myocardial Infarction [COLCOT clinical trial (28)] indicates that colchicine at a dose of $0.5 \mathrm{mg}$ daily led to a significantly lower risk of ischemic cardiovascular events than placebo (primary endpoint occurred 5.5 vs. $7.1 \%$; hazard ratio, $0.77 ; 95 \% \mathrm{CI}, 0.61$ to $0.96 ; P=0.02$ ) among patients with a recent MI. Several meta-analyses have shown that colchicine reduces the risk of future cardiovascular events, including stroke, in patients with coronary heart disease (6972). It seems that colchicine may be the fastest drug available for clinical use in the treatment of coronary atherosclerotic heart disease.

\section{Anti-inflammatory Effects of Colchicine in Atherosclerotic Heart Disease Need Further Evaluation}

The result from the COPS clinical trial, a multicenter, randomized, double-blind, placebo-controlled trial published on August 29, 2020, that showed the addition of colchicine to standard medical therapy did not significantly affect cardiovascular outcomes at 12 months in acute coronary syndrome (ACS) patients and was associated with a higher rate of mortality (29). Over the 12-month follow-up, there were 24 events in the colchicine group compared with 38 events in the placebo group experiencing the event $(p=0.09$, logrank). There was a higher rate of total death in the colchicine group ( 8 vs. $1, p=0.017$, log-rank). This result is surprising because ACS has higher levels of inflammation than chronic coronary syndrome $(73,74)$. Theoretically, by reducing the inflammatory burden, colchicine is more effective in patients with ACS.

In fact, the anti-inflammatory effects of colchicine in coronary atherosclerotic heart disease have not been effectively evaluated. In current studies, changes in levels of inflammation (e.g., CRP, IL-6, etc.) were not assessed in either LoDoCo, LoDoCo2, or COLCOT. Results from LoDoCo-MI (a pilot randomized placebo-controlled trial of colchicine after acute MI) shows that treatment with $0.5 \mathrm{mg} /$ day of colchicine was not associated with a significantly increased likelihood of achieving a CRP level $<2$ $\mathrm{mg} / \mathrm{L}$ or lower absolute levels of CRP 30 days after an acute MI (75). In terms of the mechanism, colchicine is a dose-dependent, broad-spectrum anti-inflammatory drug (64), and colchicine inhibits inflammation via NOD-like receptor family pyrin domain containing 3 (NLRP3) (NOD-, leucine-rich repeats-, and pyrin domain-containing protein 3 ); inflammasome is believed to act as a key mechanism in coronary arteriosclerotic heart disease (76-79). NLRP3 is an intracellular sensor, and the activation of NLRP3 inflammasome leads to caspase 1-dependent release of the pro-inflammatory cytokines IL-1 $\beta$ (80). Studies showed that colchicine inhibits NLRP3 inflammasome assembly by inhibiting cellular microtubules function (81-83). Thus, it is hypothesized that the use of colchicine can affect IL- $1 \beta$ and downstream levels of IL-6 and CRP via NLRP3 inflammasome (Figure 1), especially for patients after MI (77). Some researchers concluded that NLRP3 protein might not play a role in the acute development of MI due to low cardiac expression (84), which may explain the failure of colchicine to take positive results in patients with ACS. However, more evidence has proven that NLRP3 inflammasomemediated inflammation does have an important role in ACSs $(77,85)$. On the other hand, studies have also shown that colchicine does not necessarily activate NLRP3 (86). Therefore, 


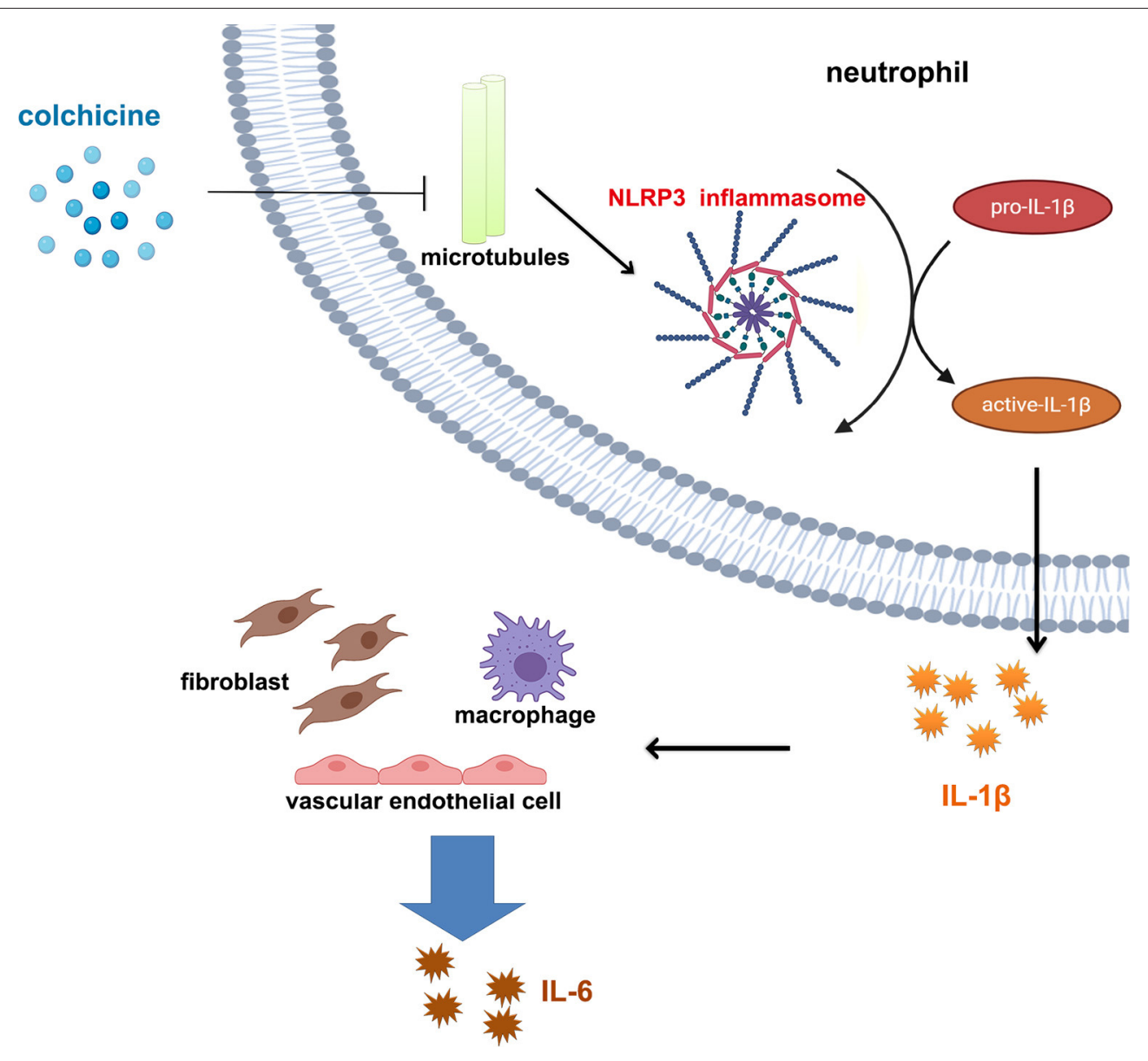

FIGURE 1 | Colchicine affects interleukin 1 $\beta$ /interleukin 6 pathway through NLRP3 inflammasome. Colchicine prevents assembly of NLRP3 inflammasome in cells by inhibiting the function of microtubules, thus reducing the maturation and release of IL-1 $\beta$ and further reducing release of IL- 6 from various types of cells.

the anti-inflammatory effects of colchicine in atherosclerotic heart disease, especially in MI, need to be further evaluated.

Another point that still needs to be investigated is whether colchicine plays an anti-inflammatory role independent of blood lipid levels. A previous study (87) have demonstrated that continuous oral administration of colchicine ( $1 \mathrm{mg} /$ day) for 1 year reduces the level of the oxidized low-density lipoprotein in patients with primary biliary cirrhosis, and a recent animal study (88) found a synergistic lipid-lowering effect of colchicine in combination with statin for a short period (2 weeks). The LoDoCo, LoDoCo2, or COLCOT studies all used secondary prevention of coronary heart disease (including statins), but none evaluated the effect of colchicine on lipids. Thus, the possibility that colchicine acts on coronary atherosclerotic heart disease by lowering blood lipids cannot be completely ruled out.

\section{SUMMARY}

In recent years, anti-inflammatory treatment of coronary atherosclerotic heart disease has achieved a stage victory. Inflammatory factor-targeted drugs such as canakinumab have confirmed the inflammatory theory of coronary heart disease, and classical anti-inflammatory drugs such as colchicine have demonstrated the possibility of rapid clinical use.

However, behind the success, there are still some questions that need to be addressed: canakinumab is expensive, has serious adverse effects, and remains a residual inflammatory risk; tocilizumab has an effect on lipid levels, its long-term effects and safety are unknown, and it is expensive; antiinflammatory effects of colchicine in atherosclerotic heart disease needs further evaluation. Moreover, during ischemia, the level of inflammation in the myocardium is also increased, thereby damaging cardiomyocytes (89), and in the case of MI, the inflammatory response triggered by dead myocardial cells further increases the size of the infarct (90-92). If the effective effects of anti-inflammatory therapy are dominated by limiting the inflammatory response of ischemic or infarcted cardiomyocytes (e.g., IL-6Ra), the use of anti-inflammatory drugs in other atherosclerotic diseases (e.g., stroke, peripheral vascular disease, etc.) may be limited.

What we can look forward to is that many studies related to the anti-inflammatory treatment of atherosclerotic disease are ongoing (Table 2 and Figure 2), including the evaluation of the protective effect of colchicine against cerebral ischemia, another 
TABLE 2 | Major ongoing clinical trials involving anti-inflammatory agents in atherosclerotic heart disease.

\begin{tabular}{|c|c|c|c|c|c|c|c|c|}
\hline Trial name & Study design & Study population & $\begin{array}{l}\text { Estimated } \\
\text { enrollment }\end{array}$ & $\begin{array}{l}\text { Estimated } \\
\text { completion } \\
\text { date }\end{array}$ & Intervention & Target & Primary outcomes & $\begin{array}{l}\text { ClinicalTrials.gov } \\
\text { identifier: }\end{array}$ \\
\hline \multicolumn{9}{|c|}{ Therapy with a clear target } \\
\hline CLEVER-ACS trial & $\begin{array}{l}\text { Phase I-II, } \\
\text { randomized, } \\
\text { paralleled, } \\
\text { placebo-controlled trial }\end{array}$ & Patients with STEMI & 150 & $\begin{array}{l}\text { December 31, } \\
2020\end{array}$ & $\begin{array}{l}\text { Everolimus }(7.5 \mathrm{mg} \\
\text { for } 3 \text { days, followed } \\
\text { By } 5 \mathrm{mg} \text { for } 2 \text { days) }\end{array}$ & mTOR & Myocardial infarct size & NCT01529554 \\
\hline \multicolumn{9}{|c|}{ Broad-spectrum anti-inflammatory approach } \\
\hline ALL-HEART study (93) & $\begin{array}{l}\text { Multicenter, controlled, prospective, } \\
\text { randomized, open-label blinded }\end{array}$ & $\begin{array}{l}\text { Patients aged } 60 \text { years and older } \\
\text { with ind }\end{array}$ & 5,215 & Unknown & $\begin{array}{l}\text { Allopurinol } \\
\text { (up to } 600 \mathrm{mg} \text { daily) }\end{array}$ & Multiple & $\begin{array}{l}\text { Composite of nonfatal } \\
\text { myocardial infarction, } \\
\text { nonfatal stroke or } \\
\text { cardiovascular death }\end{array}$ & ISRCTN32017426 \\
\hline $\begin{array}{l}\text { COACS: Colchicine for } \\
\text { Acute Coronary } \\
\text { Syndromes }\end{array}$ & $\begin{array}{l}\text { Phase III multicenter, } \\
\text { double blind, } \\
\text { randomized } \\
\text { placebo-controlled }\end{array}$ & $\begin{array}{l}\text { Patients with ACS (unstable angina } \\
\text { or acute myocardial infarction) }\end{array}$ & 500 & Unknown & $\begin{array}{l}\text { Colchicine } 0.5 \\
\text { Mg/day vs. Placebo }\end{array}$ & Multiple & $\begin{array}{l}\text { Overall mortality, new } \\
\text { acute coronary } \\
\text { syndrome, and ischemic } \\
\text { stroke }\end{array}$ & NCT01906749 \\
\hline $\begin{array}{l}\text { Colchicine and } \\
\text { Spironolactone } \\
\text { in patients with } \\
\text { STEMI/SYNERGY Stent } \\
\text { Registry }\end{array}$ & $\begin{array}{l}\text { Phase III } \\
\text { randomized } \\
\text { placebo-controlled } \\
4 \text { study arms, } 2 \times 2 \\
\text { factorial design }\end{array}$ & $\begin{array}{l}\text { Patients with MI/SYNERGY Stent } \\
\text { Registry }\end{array}$ & 7,000 & $\begin{array}{l}\text { March 30, } \\
2025\end{array}$ & $\begin{array}{l}\text { Colchicine } 1 \mathrm{mg} / \text { day } \\
\text { And/or } \\
\text { Spironolactone } 25 \\
\mathrm{mg} / \text { day and/or } \\
\text { placebo and/or } \\
\text { synergy stent }\end{array}$ & Multiple & $\begin{array}{l}\text { Major Adverse Cardiac } \\
\text { Events for SYNERGY } \\
\text { Stent (defined as the } \\
\text { composite of death, } \\
\text { recurrent target vessel } \\
\text { MI, stroke, or ischemia } \\
\text { driven target vessel } \\
\text { revascularization) }\end{array}$ & NCT03048825 \\
\hline CONVINCE & $\begin{array}{l}\text { Phase III multicenter, } \\
\text { Open-label, placebo controlled }\end{array}$ & $\begin{array}{l}\text { Patients older than } 40 \text { years of age } \\
\text { who have suffered an ischemic } \\
\text { stroke or transient ischemic attack } \\
\text { not caused by cardiac embolism or } \\
\text { other defined causes }\end{array}$ & 2,623 & October 2021 & $\begin{array}{l}\text { Colchicine } 0.5 \\
\text { mg/day vs. placebo }\end{array}$ & Multiple & $\begin{array}{l}\text { Nonfatal recurrent } \\
\text { ischemic stroke and } \\
\text { coronary events and } \\
\text { vascular death }\end{array}$ & NCT02898610 \\
\hline
\end{tabular}

Cl, confidence interval; HR, hazard ratio; MI, myocardial infarction; STEMI, ST-segment elevation myocardial infarction; ACS, acute coronary syndrome; mTOR, mechanistic target of rapamycin; IHD, ischemic heart disease. 


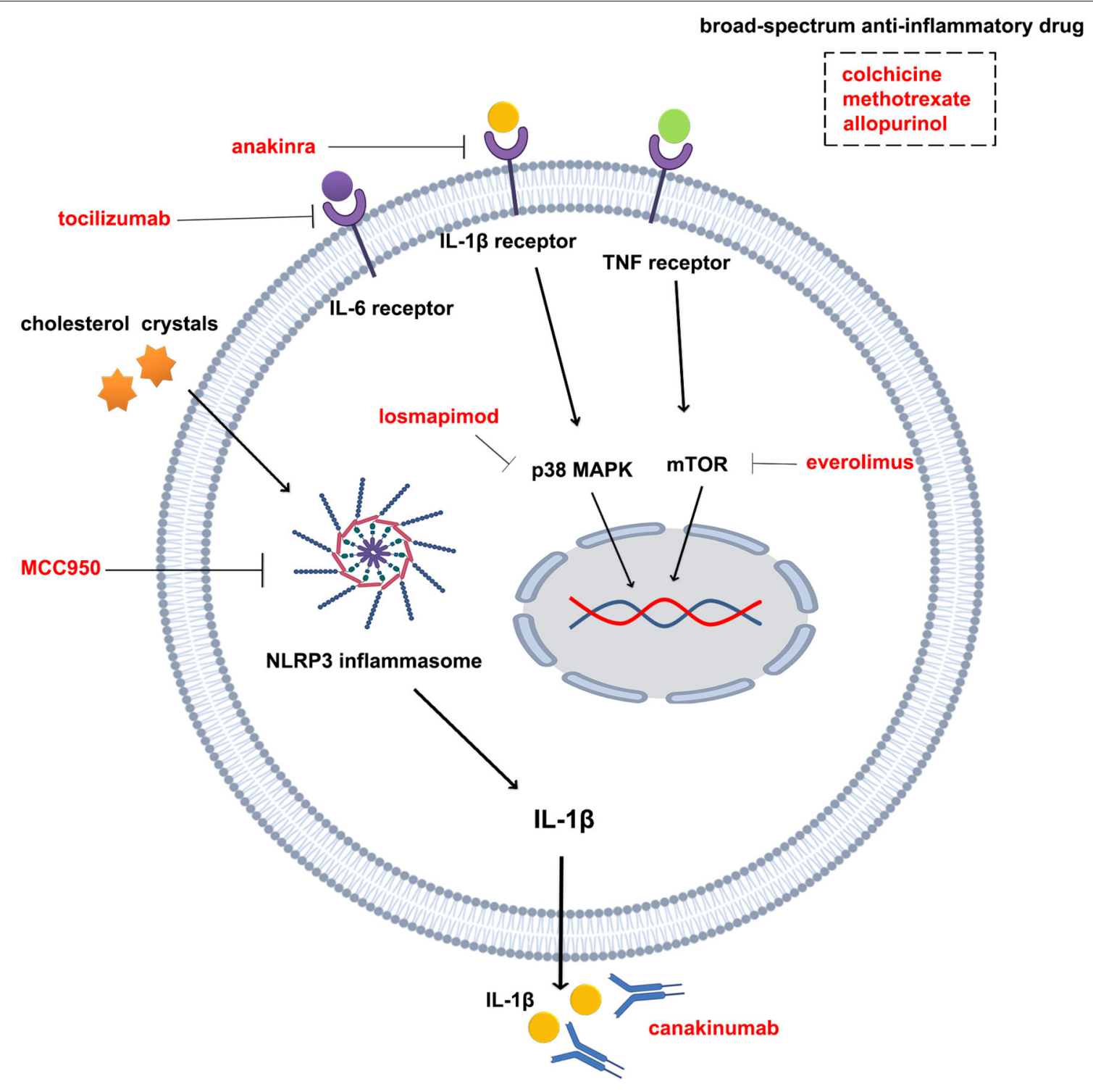

FIGURE 2 | Drugs and targets for anti-inflammatory therapy in atherosclerotic diseases. Tocilizumab is an interleukin-6 receptor antagonist; anakinra is an interleukin $1 \beta$ receptor antagonist; canakinumab is an interleukin $1 \beta$ monoclonal antibody; losmapimod is a p38 MAPK inhibitor; everolimus is an mTOR inhibitor; MCC950 is an NLRP3 inflammasome inhibitor; colchicine, methotrexate, and allopurin are broad-spectrum anti-inflammatory drugs.

clinical trials of colchicine in ACS and other anti-inflammatory drugs (e.g., Allopurinol, EVERolimus). These subsequent studies will provide strong evidence for determining the feasibility of anti-inflammatory therapy in coronary heart disease and even in atherosclerotic disease. In addition, NLRP3 inflammasomes are closely associated with colchicine, IL-1 $\beta$, and IL- 6 and are thought to be potentially important targets for anti-inflammatory treatment of atherosclerotic heart disease (94-97). MCC950, an NLRP3 inflammasome inhibitor, reduces infarct size and preserves cardiac function in a randomized, blinded translational large animal MI model (92). Thus, despite some unsolved mysteries, the results of the clinical research on colchicine, IL$1 \beta$ antibodies, and IL-6Ra have undoubtedly led to a victory in the anti-inflammatory treatment of atherosclerotic heart disease. Under the influence of these three successes, the path of antiinflammatory therapy for atherosclerotic diseases is flourishing.

\section{AUTHOR CONTRIBUTIONS}

All authors listed have made a substantial, direct and intellectual contribution to the work, and approved it for publication.

\section{FUNDING}

This project was supported by grants from the National Natural Science Foundation of China (Nos. 81900404, and 81970355). 


\section{REFERENCES}

1. Knuuti J, Wijns W, Saraste A, Capodanno D, Barbato E, Funck-Brentano C, et al. 2019 ESC Guidelines for the diagnosis and management of chronic coronary syndromes. Eur Heart J. (2020) 41:407-77. doi: 10.1093/eurheartj/ehz425

2. Arnett Donna K, Blumenthal Roger S, Albert Michelle A, Buroker Andrew B, Goldberger Zachary D, Hahn Ellen J, et al. 2019 ACC/AHA Guideline on the Primary Prevention of Cardiovascular Disease. J Am College Cardiol. (2019) 74:e177-e232. doi: 10.1016/j.jacc.2019.03.010

3. Pencina Michael J, Navar Ann M, Wojdyla D, Sanchez Robert J, Khan I, Elassal J, et al. Quantifying importance of major risk factors for coronary heart disease. Circulation. (2019) 139:1603-11. doi: 10.1161/CIRCULATIONAHA.117.031855

4. Cholesterol Treatment Trialists C, Mihaylova B, Emberson J, Blackwell L, Keech A, Simes J, et al. The effects of lowering IDL cholesterol with statin therapy in people at low risk of vascular disease: meta-analysis of individual data from 27 randomised trials. Lancet. (2012) 380:581-90. doi: 10.1016/S0140-6736(12)60367-5

5. Kang J, Park KW, Lee MS, Zheng C, Han J-K, Yang H-M, et al. The natural course of nonculprit coronary artery lesions; analysis by serial quantitative coronary angiography. BMC Cardiovasc Disord. (2018) 18:130. doi: $10.1186 / s 12872-018-0870-9$

6. Hansson Göran K. Inflammation and atherosclerosis. Circulation. (2017) 136:1875-7. doi: 10.1161/CIRCULATIONAHA.117.030484

7. Wolf D Ley K. Immunity and inflammation in atherosclerosis. Circ Res. (2019) 124:315-27. doi: 10.1161/CIRCRESAHA.118.313591

8. Raggi P, Genest J, Giles JT, Rayner KJ, Dwivedi G, Beanlands RS Gupta M. Role of inflammation in the pathogenesis of atherosclerosis and therapeutic interventions. Atherosclerosis. (2018) 276:98-108. doi: 10.1016/j.atherosclerosis.2018.07.014

9. Çukurova S, Pamuk ÖN, Ünlü E, Pamuk GE Çakir N. Subclinical atherosclerosis in gouty arthritis patients: a comparative study. Rheum Int. (2012) 32:1769-73. doi: 10.1007/s00296-011-1900-4

10. Andrés M, Bernal JA, Sivera F, Quilis N, Carmona L, Vela P Pascual E. Cardiovascular risk of patients with gout seen at rheumatology clinics following a structured assessment. Ann Rheum Dis. (2017) 76:1263-8. doi: 10.1136/annrheumdis-2016-210357

11. Chung CP, Oeser A, Raggi P, Gebretsadik T, Shintani AK, Sokka T, et al. Increased coronary-artery atherosclerosis in rheumatoid arthritis: relationship to disease duration and cardiovascular risk factors. Arth Rheum. (2005) 52:3045-53. doi: 10.1002/art.21288

12. Shoenfeld Y, Gerli R, Doria A, Matsuura E, Cerinic MM, Ronda N, et al. Accelerated atherosclerosis in autoimmune rheumatic diseases. Circulation. (2005) 112:3337-47. doi: 10.1161/CIRCULATIONAHA.104.507996

13. Nissen SE, Tuzcu EM, Schoenhagen P, Crowe T, Sasiela WJ, Tsai J, et al. Statin therapy, LDL cholesterol, c-reactive protein, and coronary artery disease. $N$ Engl J Med. (2005) 352:29-38. doi: 10.1056/NEJMoa042000

14. Ridker PM, Cannon CP, Morrow D, Rifai N, Rose LM, McCabe CH, et al. CReactive protein levels and outcomes after statin therapy. N Engl J Med. (2005) 352:20-8. doi: 10.1056/NEJMoa042378

15. Bohula Erin A, Giugliano Robert P, Cannon Christopher P, Zhou J, Murphy Sabina A, White Jennifer A, et al. Achievement of dual lowdensity lipoprotein cholesterol and high-Sensitivity c-Reactive protein targets more frequent with the addition of ezetimibe to simvastatin and associated with better outcomes in iMPROVE-IT. Circulation. (2015) 132:1224-33. doi: 10.1161/CIRCULATIONAHA.115.018381

16. Ridker Paul M. Anticytokine agents. Circ Res. (2019) 124:437-50. doi: 10.1161/CIRCRESAHA.118.313129

17. Ridker PM, Danielson E, Fonseca FAH, Genest J, Gotto AM, Kastelein JJP, et al. Rosuvastatin to prevent vascular events in men and women with elevated c-reactive protein. N Engl J Med. (2008) 359:2195-207. doi: 10.1056/NEJMoa0807646

18. Munford RS. Statins and the acute-Phase response. N Engl J Med. (2001) 344:2016-8. doi: 10.1056/NEJM200106283442609

19. Ridker PM, Everett BM, Thuren T, MacFadyen JG, Chang WH, Ballantyne C, et al. Antiinflammatory therapy with canakinumab for atherosclerotic disease. N Engl J Med. (2017) 377:1119-31. doi: 10.1056/NEJMoa1707914
20. Ridker PM, Everett BM, Pradhan A, MacFadyen JG, Solomon DH, Zaharris E, et al. Low-Dose methotrexate for the prevention of atherosclerotic events. $N$ Engl J Med. (2018) 380:752-62. doi: 10.1056/NEJMoa1809798

21. Nidorf Stefan M, Eikelboom John W, Budgeon Charley A Thompson Peter L. Low-Dose colchicine for secondary prevention of cardiovascular disease. $J$ Am Coll Cardiol. (2013) 61:404-10. doi: 10.1016/j.jacc.2012.10.027

22. Nidorf SM, Fiolet ATL, Mosterd A, Eikelboom JW, Schut A, Opstal TSJ, et al. Colchicine in patients with chronic coronary disease. N Engl J Med. (2020) 32:2045-51. doi: 10.1056/NEJMoa2021372

23. Kleveland O, Kunszt G, Bratlie M, Ueland T, Broch K, Holte E, et al. Effect of a single dose of the interleukin- 6 receptor antagonist tocilizumab on inflammation and troponin $\mathrm{T}$ release in patients with non-ST-elevation myocardial infarction: a double-blind, randomized, placebo-controlled phase 2 trial $^{\dagger}$. Eur Heart J. (2016) 37:2406-13. doi: 10.1093/eurheartj/ehw171

24. Anstensrud AK, Woxholt S, Sharma K, Broch K, Bendz B, Aakhus S, et al. Rationale for the aSSAIL-MI-trial: a randomised controlled trial designed to assess the effect of tocilizumab on myocardial salvage in patients with acute sT-elevation myocardial infarction (STEMI). Open Heart. (2019) 6:e001108. doi: 10.1136/openhrt-2019-001108

25. Morton AC, Rothman AMK, Greenwood JP, Gunn J, Chase A, Clarke B, et al. The effect of interleukin-1 receptor antagonist therapy on markers of inflammation in non-ST elevation acute coronary syndromes: the mRC-ILA heart study. Eur Heart J. (2015) 36:377-84. doi: 10.1093/eurheartj/ehu272

26. O’Donoghue ML, Glaser R, Cavender MA, Aylward PE, Bonaca MP, Budaj A, et al. Effect of losmapimod on cardiovascular outcomes in patients hospitalized with acute myocardial infarction: a Randomized clinical trial. JAMA. (2016) 315:1591-9. doi: 10.1001/jama.2016.3609

27. O'Donoghue ML, Braunwald E, White HD, Steen DL, Lukas MA, Tarka E, et al. Effect of darapladib on major coronary events after an acute coronary syndrome: the sOLID-TIMI 52 randomized clinical trial. JAMA. (2014) 312:1006-15. doi: 10.1001/jama.2014.11061

28. Tardif J-C, Kouz S, Waters DD, Bertrand OF, Diaz R, Maggioni AP, et al. Efficacy and safety of low-Dose colchicine after myocardial infarction. $N$ Engl J Med. (2019) 381:2497-505. doi: 10.1056/NEJMoa1912388

29. Tong David C, Quinn S, Nasis A, Hiew C, Roberts-Thomson P, Adams $\mathrm{H}$, et al. Colchicine in patients with acute coronary syndrome: the Australian COPS randomized clinical trial. Circulation. (2020) 142:1890-900. doi: 10.1161/CIRCULATIONAHA.120.050771

30. Libby P. Inflammation in atherosclerosis. Arterioscler Thromb Vasc Biol. (2012) 32:2045-51. doi: 10.1161/ATVBAHA.108.179705

31. Ross R. Atherosclerosis - an inflammatory disease. N Engl J Med. (1999) 340:115-26. doi: 10.1056/NEJM199901143400207

32. Berk BC, Weintraub WS Alexander RW. Elevation of c-reactive protein in "active" coronary artery disease. Am J Cardiol. (1990) 65:168-72. doi: 10.1016/0002-9149(90)90079-G

33. Liuzzo G, Biasucci LM, Gallimore JR, Grillo RL, Rebuzzi AG, Pepys MB Maseri A. The prognostic value of c-reactive protein and serum amyloid a protein in severe unstable angina. N Engl J Med. (1994) 331:417-24. doi: 10.1056/NEJM199408183310701

34. Haverkate F, Thompson SG, Pyke SD, Gallimore JR Pepys MB. Production of c-reactive protein and risk of coronary events in stable and unstable angina. European concerted action on thrombosis and disabilities angina pectoris study group. Lancet. (1997) 349:462-6. doi: 10.1016/S0140-6736(96)07591-5

35. Ridker PM, Cushman M, Stampfer MJ, Tracy RP Hennekens $\mathrm{CH}$. Inflammation, aspirin, and the risk of cardiovascular disease in apparently healthy men. $N$ Engl J Med. (1997) 336:973-79. doi: 10.1056/NEJM199704033361401

36. Zacho J, Tybjærg-Hansen A, Jensen JS, Grande P, Sillesen H Nordestgaard BG. Genetically elevated c-Reactive protein and ischemic vascular disease. $N$ Engl J Med. (2008) 359:1897-908. doi: 10.1056/NEJMoa0707402

37. Ridker PM, Rifai N, Clearfield M, Downs JR, Weis SE, Miles JS. Measurement of C-reactive protein for the targeting of statin therapy in the primary prevention of acute coronary events. N Engl J Med. (2001) 344:1959-65. doi: 10.1056/NEJM200106283442601

38. Lindmark E, Diderholm E, Wallentin L Siegbahn A. Relationship between interleukin 6 and mortality in patients with unstable coronary artery diseaseEffects of an early invasive or noninvasive strategy. JAMA. (2001) 286:2107-13. doi: 10.1001/jama.286.17.2107 
39. Ridker PM. From c-Reactive protein to interleukin-6 to interleukin-1: moving upstream to identify novel targets for atheroprotection. Circ Res. (2016) 118:145-56. doi: 10.1161/CIRCRESAHA.115.306656

40. Schieffer B, Selle T, Hilfiker A, Hilfiker-Kleiner D, Grote K, Tietge UJ, et al. Impact of interleukin-6 on plaque development and morphology in experimental atherosclerosis. Circulation. (2004) 110:3493-500. doi: 10.1161/01.CIR.0000148135.08582.97

41. Kinlay S, Timms T, Clark M, Karam C, Bilodeau T, Ridker PM, et al. Comparison of effect of intensive lipid lowering with atorvastatin to less intensive lowering with lovastatin on c-reactive protein in patients with stable angina pectoris and inducible myocardial ischemia. Am J Cardiol. (2002) 89:1205-7. doi: 10.1016/S0002-9149(02)02306-8

42. Ridker PM, Rifai N, Stampfer MJ Hennekens CH. Plasma concentration of interleukin-6 and the risk of future myocardial infarction among apparently healthy men. Circulation. (2000) 101:1767-72. doi: 10.1161/01.CIR.101.15.1767

43. Swerdlow DI, Holmes MV, Kuchenbaecker KB, Engmann JE, Shah T, Sofat R, et al. The interleukin- 6 receptor as a target for prevention of coronary heart disease: a mendelian randomisation analysis. Lancet. (2012) 379:1214-24.

44. Kawashiri SY, Kawakami A, Yamasaki S, Imazato T, Iwamoto N, Fujikawa $\mathrm{K}$, et al. Effects of the anti-interleukin-6 receptor antibody, tocilizumab, on serum lipid levels in patients with rheumatoid arthritis. Rheumatol Int. (2011) 31:451-6. doi: 10.1007/s00296-009-1303-y

45. McInnes IB, Thompson L, Giles JT, Bathon JM, Salmon JE, Beaulieu AD, et al. Effect of interleukin- 6 receptor blockade on surrogates of vascular risk in rheumatoid arthritis: mEASURE, a randomised, placebo-controlled study. Ann Rheum Dis. (2015) 74:694-702. doi: 10.1136/annrheumdis-2013-204345

46. Strang AC, Bisoendial RJ, Kootte RS, Schulte DM, Dallinga-Thie GM, Levels $\mathrm{JH}$, et al. Pro-atherogenic lipid changes and decreased hepatic LDL receptor expression by tocilizumab in rheumatoid arthritis. Atherosclerosis. (2013) 229:174-81. doi: 10.1016/j.atherosclerosis.2013.04.031

47. Akita K, Isoda K, Sato-Okabayashi Y, Kadoguchi T, Kitamura K, Ohtomo F, et al. An interleukin-6 receptor antibody suppresses atherosclerosis in atherogenic mice. Front Cardiovasc Med. (2017) 4:84. doi: $10.3389 /$ fcvm.2017.00084

48. Peeters W, Hellings WE, Kleijn DPVd, Vries JPPMd, Moll FL, Vink A Pasterkamp G. Carotid atherosclerotic plaques stabilize after stroke. Arteriosc Throm Vasc Biol. (2009) 29:128-33. doi: 10.1161/ATVBAHA.108.173658

49. Schieffer B, Schieffer E, Hilfiker-Kleiner D, Hilfiker A, Kovanen PT, Kaartinen M, et al. Expression of angiotensin iI and interleukin 6 in human coronary atherosclerotic plaques. Circulation. (2000) 101:1372-8. doi: 10.1161/01.CIR.101.12.1372

50. Kobara M, Noda K, Kitamura M, Okamoto A, Shiraishi T, Toba H, et al. Antibody against interleukin-6 receptor attenuates left ventricular remodelling after myocardial infarction in mice. Cardiovasc Res. (2010) 87:424-30. doi: 10.1093/cvr/cvq078

51. Ritschel VN, Seljeflot I, Arnesen H, Halvorsen S, Eritsland J, Fagerland MW Andersen GØ. Circulating levels of iL-6 receptor and gp130 and long-Term clinical outcomes in sT-Elevation myocardial infarction. J Am Heart Assoc. (2016) 5:e003014. doi: 10.1161/JAHA.115.003014

52. Damas P, Ledoux D, Nys M, Vrindts Y, De Groote D, Franchimont $\mathrm{P}$ Lamy M. Cytokine serum level during severe sepsis in human iL-6 as a marker of severity. Ann Surg. (1992) 215:356-362. doi: 10.1097/00000658-199204000-00009

53. Xing Z, Gauldie J, Cox G, Baumann H, Jordana M, Lei XF Achong MK. IL-6 is an antiinflammatory cytokine required for controlling local or systemic acute inflammatory responses. J Clin Invest. (1998) 101:311-20. doi: $10.1172 /$ JCI1368

54. Tanaka $\mathrm{T}$ Kishimoto $\mathrm{T}$. Targeting interleukin-6: all the way to treat autoimmune and inflammatory diseases. Int J Biol Sci. (2012) 8:1227-36. doi: 10.7150/ijbs.4666

55. Tanaka T, Narazaki M Kishimoto T. Therapeutic targeting of the interleukin-6 receptor. Ann Rev Pharmacol Toxicol. (2012) 52:199-219. doi: 10.1146/annurev-pharmtox-010611-134715

56. Qamar A Rader DJ. Effect of interleukin $1 \beta$ inhibition in cardiovascular disease. Curr Opin Lipidol. (2012) 23:548-53. doi: 10.1097/MOL.0b013e328359b0a6
57. Kirii $H$, Niwa $T$, Yamada $Y$, Wada $H$, Saito $K$, Iwakura $Y$, et al. Lack of interleukin-1 $\beta$ decreases the severity of atherosclerosis in apoE-Deficient mice. Arterioscl Thromb Vasc Biol. (2003) 23:656-60. doi: 10.1161/01.ATV.0000064374.15232.C3

58. Everett Brendan M, MacFadyen Jean G, Thuren T, Libby P, Glynn Robert J Ridker Paul M. Inhibition of interleukin- $1 \beta$ and reduction in atherothrombotic cardiovascular events in the cANTOS trial. J Am Coll Cardiol. (2020) 76:1660-70. doi: 10.1016/j.jacc.2020.08.011

59. Ridker PM, MacFadyen JG, Thuren T, Libby P Group obotCT. Residual inflammatory risk associated with interleukin-18 and interleukin-6 after successful interleukin-1 $\beta$ inhibition with canakinumab: further rationale for the development of targeted anti-cytokine therapies for the treatment of atherothrombosis. Eur Heart J. (2019) 41:2153-63. doi: 10.1093/eurheartj/ehz542

60. Gomez D, Baylis RA, Durgin BG, Newman AAC, Alencar GF, Mahan S, et al. Interleukin- $1 \beta$ has atheroprotective effects in advanced atherosclerotic lesions of mice. Nat Med. (2018) 24:1418-29. doi: 10.1038/s41591-018-0124-5

61. Cronstein BN, Molad Y, Reibman J, Balakhane E, Levin RI Weissmann G. Colchicine alters the quantitative and qualitative display of selectins on endothelial cells and neutrophils. J Clin Invest. (1995) 96:994-1002. doi: 10.1172/JCI118147

62. Nuki G. Colchicine: its mechanism of action and efficacy in crystal-induced inflammation. Curr Rheumatol Rep. (2008) 10:218. doi: 10.1007/s11926-008-0036-3

63. Tristan P Pascal R. Colchicine in gout: an update. Curr Pharm Design. (2018) 24:684-689. doi: 10.2174/1381612824999180115103951

64. Slobodnick A, Shah B, Krasnokutsky S Pillinger MH. Update on colchicine, 2017. Rheumatology. (2018) 57:i4-i11. doi: 10.1093/rheumatology/kex453

65. Indraratna PL, Virk S, Gurram D Day RO. Use of colchicine in pregnancy: a systematic review and meta-analysis. Rheumatology. (2017) 57:382-7. doi: 10.1093/rheumatology/kex353

66. Richette P, Doherty M, Pascual E, Barskova V, Becce F, CastañedaSanabria J, et al. 2016 updated EULAR evidence-based recommendations for the management of gout. Ann Rheum Dis. (2017) 76:29-42. doi: 10.1136/annrheumdis-2016-209707

67. Crittenden DB, Lehmann RA, Schneck L, Keenan RT, Shah B, Greenberg $\mathrm{JD}$, et al. Colchicine use is associated with decreased prevalence of myocardial infarction in patients with gout. J Rheum. (2012) 39:1458-64. doi: 10.3899/jrheum.111533

68. Solomon DH, Liu C-C, Kuo I-H, Zak A Kim SC. Effects of colchicine on risk of cardiovascular events and mortality among patients with gout: a cohort study using electronic medical records linked with medicare claims. Ann Rheum Dis. (2016) 75:1674-9. doi: 10.1136/annrheumdis-2015-207984

69. Verma S, Eikelboom JW, Nidorf SM, Al-Omran M, Gupta N, Teoh H Friedrich JO. Colchicine in cardiac disease: a systematic review and metaanalysis of randomized controlled trials. BMC Cardiovasc Disord. (2015) 15:96. doi: 10.1186/s12872-015-0068-3

70. Xia M, Yang X Qian C. Meta-analysis evaluating the utility of colchicine in secondary prevention of coronary artery disease. Am J Cardiol. (2020) 140:33-38. doi: 10.1016/j.amjcard.2020.10.043

71. Tien YY, Huang HK, Shih MC Tu YK. Drug repurposing? Cardiovascular effect of colchicine on patients with coronary artery disease: A systematic review and meta-analysis. J Cardiol. (2020) doi: 10.1016/j.jjcc.2020.11.010

72. Katsanos AH, Palaiodimou L, Price C, Giannopoulos S, Lemmens R, Kosmidou M, et al. Colchicine for stroke prevention in patients with coronary artery disease: a systematic review and meta-analysis. Eur J Neurol. (2020) 27:1035-8. doi: 10.1111/ene.14198

73. Abdelmouttaleb I, Danchin N, Ilardo C, Aimone-Gastin I, Angiö M, Lozniewski A, et al. C-Reactive protein and coronary artery disease: additional evidence of the implication of an inflammatory process in acute coronary syndromes. Am Heart J. (1999) 137:346-51. doi: 10.1053/hj.1999.v137.92052

74. Maseri A Cianflone D. Inflammation in acute coronary syndromes. Eur Heart J Suppl. (2002) 4:B8-B13. doi: 10.1016/S1520-765X(02)90009-X

75. Hennessy T, Soh L, Bowman M, Kurup R, Schultz C, Patel S Hillis GS. The low dose colchicine after myocardial infarction (LoDoCo-MI) study: a pilot randomized placebo controlled trial of colchicine following acute myocardial infarction. Am Heart J. (2019) 215:62-9. doi: 10.1016/j.ahj.2019.06.003 
76. Martínez GJ, Celermajer DS Patel S. The NLRP3 inflammasome and the emerging role of colchicine to inhibit atherosclerosisassociated inflammation. Atherosclerosis. (2018) 269:262-71. doi: 10.1016/j.atherosclerosis.2017.12.027

77. Toldo S Abbate A. The NLRP3 inflammasome in acute myocardial infarction. Nat Rev Cardiol. (2018) 15:203-14. doi: 10.1038/nrcardio.2017.161

78. Arbel Y, Abuzeid W, Rosenson RS, Weisman A Farkouh ME. Old drugs for new indications in cardiovascular medicine. Cardiovasc Drugs Ther. (2018) 32:223-32. doi: 10.1007/s10557-018-6785-y

79. Imazio M, Andreis A, Brucato A, Adler Y De Ferrari GM. Colchicine for acute and chronic coronary syndromes. Heart. (2020) 106:1555-60. doi: 10.1136/heartjnl-2020-317108

80. Swanson KV, Deng M Ting JPY. The nLRP3 inflammasome: molecular activation and regulation to therapeutics. Nat Rev Immunol. (2019) 19:477-89. doi: 10.1038/s41577-019-0165-0

81. Martinon F, Pétrilli V, Mayor A, Tardivel A Tschopp J. Gout-associated uric acid crystals activate the NALP3 inflammasome. Nature. (2006) 440:237-41. doi: 10.1038 /nature 04516

82. Misawa T, Takahama M, Kozaki T, Lee H, Zou J, Saitoh T Akira S. Microtubule-driven spatial arrangement of mitochondria promotes activation of the NLRP3 inflammasome. Nat Immunol. (2013) 14:454-60. doi: $10.1038 /$ ni. 2550

83. Van Gorp H, Saavedra PHV, de Vasconcelos NM, Van Opdenbosch N, Vande Walle L, Matusiak M, et al. Familial mediterranean fever mutations lift the obligatory requirement for microtubules in pyrin inflammasome activation. Proc Natl Acad Sci USA. (2016) 113:14384-9. doi: 10.1073/pnas.16131 56113

84. Jong WM, Leemans JC, Weber NC, Juffermans NP, Schultz MJ, Hollmann MW Zuurbier CJ. Nlrp3 plays no role in acute cardiac infarction due to low cardiac expression. Int J Cardiol. (2014) 177:41-3. doi: 10.1016/j.ijcard.2014.09.148

85. Silvis MJM, Demkes EJ, Fiolet ATL, Dekker M, Bosch L, van Hout GPJ, et al. Immunomodulation of the nLRP3 inflammasome in atherosclerosis, coronary artery disease, and acute myocardial infarction. J Cardiovasc Transl Res. (2020). doi: 10.1007/s12265-020-10049-w

86. He Y, Zeng MY, Yang D, Motro B Núñez G. NEK7 is an essential mediator of nLRP3 activation downstream of potassium efflux. Nature. (2016) 530:354-57. doi: $10.1038 /$ nature 16959

87. Vuoristo M, Fäarkkilä M, Karvonen A-L, Leino R, Lehtola J, Mäkinen J, et al. A placebo-controlled trial of primary biliary cirrhosis treatment with colchicine and ursodeoxycholic acid. Gastroenterology. (1995) 108:1470-8. doi: 10.1016/0016-5085(95)90696-7

88. Huang C, Cen C, Wang C, Zhan H Ding X. Synergistic effects of colchicine combined with atorvastatin in rats with hyperlipidemia. Lipids Health Dis. (2014) 13:67. doi: 10.1186/1476-511 X-13-67

89. Arslan F, de Kleijn DP Pasterkamp G. Innate immune signaling in cardiac ischemia. Nat Rev Cardiol. (2011) 8:292-300. doi: 10.1038/nrcardio.2011.38

90. Timmers L, Pasterkamp G, de Hoog VC, Arslan F, Appelman Y de Kleijn DPV. The innate immune response in reperfused myocardium. Cardiovasc Res. (2012) 94:276-83. doi: 10.1093/cvr/cvs018

91. Mahtta D, Sudhakar D, Koneru S, Silva GV, Alam M, Virani SS Jneid H. Targeting inflammation after myocardial infarction. Curr Cardiol Rep. (2020) 22:110. doi: 10.1007/s11886-020-01358-2

92. van Hout GP, Bosch L, Ellenbroek GH, de Haan JJ, van Solinge WW, Cooper MA, et al. The selective nLRP3-inflammasome inhibitor mCC950 reduces infarct size and preserves cardiac function in a pig model of myocardial infarction. Eur Heart J. (2017) 38:828-836. doi: 10.1093/eurheartj/ehw247

93. Mackenzie IS, Ford I, Walker A, Hawkey C, Begg A, Avery A, et al. Multicentre, prospective, randomised, open-label, blinded end point trial of the efficacy of allopurinol therapy in improving cardiovascular outcomes in patients with ischaemic heart disease: protocol of the aLL-HEART study. BMJ Open. (2016) 6:e013774. doi: 10.1136/bmjopen-2016-013774

94. Duewell P, Kono H, Rayner KJ, Sirois CM, Vladimer G, Bauernfeind FG, et al. NLRP3 inflammasomes are required for atherogenesis and activated by cholesterol crystals. Nature. (2010) 464:1357-61. doi: 10.1038/nature08938

95. Grebe A, Hoss F Latz E. NLRP3 inflammasome and the iL1 pathway in atherosclerosis. Circ Res. (2018) 122:1722-40. doi: 10.1161/CIRCRESAHA.118.311362

96. Paramel Varghese G, Folkersen L, Strawbridge Rona J, Halvorsen B, Yndestad A, Ranheim T, et al. NLRP3 inflammasome expression and activation in human atherosclerosis. J Am Heart Assoc. (2016) 5:e003031. doi: 10.1161/JAHA.115.003031

97. Xiao H, Lu M, Lin Ting Y, Chen Z, Chen G, Wang W-C, et al. Sterol regulatory element binding protein 2 activation of nLRP3 inflammasome in endothelium mediates hemodynamic-Induced atherosclerosis susceptibility. Circulation. (2013) 128:632-42. doi: 10.1161/CIRCULATIONAHA.113.002714

Conflict of Interest: The authors declare that the research was conducted in the absence of any commercial or financial relationships that could be construed as a potential conflict of interest.

Copyright (C) $2021 \mathrm{Ma}$ and Chen. This is an open-access article distributed under the terms of the Creative Commons Attribution License (CC BY). The use, distribution or reproduction in other forums is permitted, provided the original author(s) and the copyright owner(s) are credited and that the original publication in this journal is cited, in accordance with accepted academic practice. No use, distribution or reproduction is permitted which does not comply with these terms. 